\title{
When Christology intersects with embryology: the viewpoints of Nestorian, Monophysite and Chalcedonian authors of the sixth to tenth centuries
}

\begin{abstract}
The notion that the soul comes into existence simultaneously with the body at the moment of conception was originally introduced into the Patristic discourse as an alternative to the Origenist notion of a pre-existing soul. Yet from the sixth century onwards it was itself regarded as an Origenist tenet. Now it was claimed that only those who believed the soul to be created after the body were truly orthodox. The present article examines the links between this development and the Christological conversies.
\end{abstract}

Adresse: Dr. Dirk Krausmüller, Gratian-Marx-Str. 8/25, 1110 Wien, ÖsTERREICH; dkrausmuller@hotmail.com

In Patristic literature the ensoulment of the embryo is explained in three different ways: the soul either pre-exists the body and enters it at the moment of conception (prohyparxis), or comes into being at the moment of conception (synhyparxis), or appears after the body has been formed (methyparxis). From the late fourth century onwards the first option, which had once been proposed by Origen, met with increasing resistence since many considered it to be irreconcilable with the Christian faith. By contrast, the second and third options were widely regarded as equally orthodox. Their proponents disagreed but did so without rancour as nothing much was at stake. This situation, however, changed in the middle of the sixth century when two developments took place. On the one hand, not only prohyparxis but also synhyparxis was now widely suspected

\footnotetext{
This article is part of the project "Reassessing ninth century philosophy. A synchronic approach to the logical traditions" (9SALT) that has received funding from the European Research Council (ERC) under the European Union's Horizon 2020 research and innovation programme (grant agreement No. 64298).
} 
of being an Origenist position, and on the other hand, the Christological implications of the different positions were seen more clearly than before. This article makes the case that Nestorians, Monophysites and Chalcedonians chose the option that best fitted their understanding of the incarnation and at the same time allowed the most effective polemic. Accordingly, it does not offer an exhaustive discussion of all evidence regarding the ensoulment of the embryo but deals mainly with texts where the specific case of Christ's body and soul is discussed. The timeframe is between the sixth and the tenth century. The debate is not always continuous and it is not always possible to situate a particular statement in its historical context. Yet comparison of the texts shows that the representatives of the different views were cognizant of alternative interpretations. ${ }^{1}$

Before delving into the discussion a few words are in order about the terms of the debate. Those who were in favour of prohyparxis borrowed from Platonic philosophy the notion of an ever-moving and self-moving soul. ${ }^{2}$ The champions of synhyparxis also turned to Plato but chose a more selective approach since they only sought to prove that the soul was fully developed at the moment of conception. Those who defended methyparxis could appeal to Scripture and to Aristotle. In the first case three verses played an important role: Genesis 2:7: 'And God formed the human being as dust from the earth and breathed into his face a

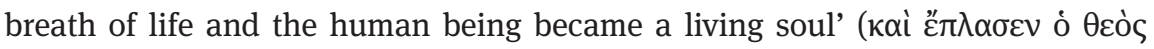

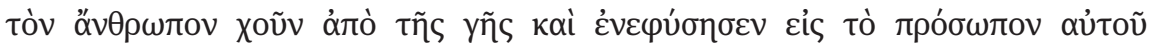

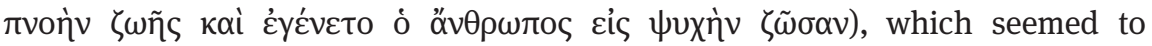
imply a temporal sequence; Exodus 21:22-23: 'But when two men fight and hit a pregnant woman and her child comes out not yet figured, he shall be made to pay the penalty, as the husband of the woman may lay upon him, he shall pay with a valuation, but if it is figured he shall give a soul for a soul'

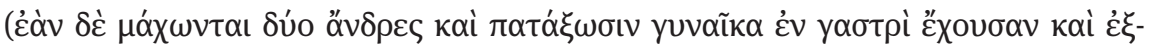

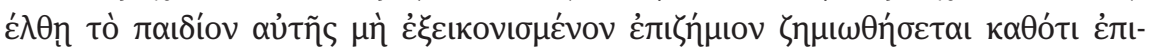

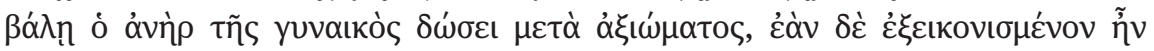

1 The debate between creatianists and traducianists will not be considered since all authors discussed in this article were creatianists of one stripe or another. See R. HenNings, Disputatio de origine animae (CPL 623, 37) or the victory of creatianism in the fifth century, in E. A. Livingstone (ed.), Studia Patristica 30. Leuven 1997, 260-268. This does, of course, not mean that there were no longer any traducianists. See Symeon Stylites (the Younger of Antioch), Sermo 15; ed. A. MAI, Nova Patrum Bibliotheca VIII/3. Rome 1871, 66-73, which dates to the later sixth century.

2 Plato, Phaedrus, 245c5-246a1. See D. Blyth, The ever-moving soul in Plato's "Phaedrus". The American Journal of Philology 118 (1997), 185-217, esp. 194-195. 


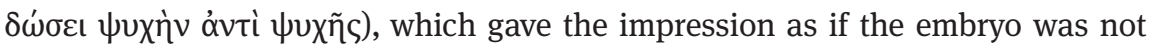
considered a human being before the formation of the body was completed; and Zachariah 12:1 'Says the Lord ... who forms the spirit of a human being in him’ ( that the soul was created in an already existing body. In the second case the main point of reference was two treatises of Aristotle, De anima and De generatione animalium. According to De anima a sequence of souls appears in the human embryo, first the nutritive soul, which is also found in plants and is responsible for growth and nutrition, then the sensitive soul, which is also found in animals and is responsible for movement and perception, and lastly the rational soul, which is only found in human beings and which appears when the body is fully formed. ${ }^{3}$ By contrast, De generatione animalium introduces the notion of a mind that comes from the outside. ${ }^{4}$ Knowledge of these theories was mediated through the commentary tradition where it was debated whether or not Aristotle considered the highest faculty to be separable from the body. ${ }^{5}$

Towards the end of the fourth century the bishop and theologian Gregory of Nyssa composed the treatise De hominis opificio in which he set out his views about the make-up of the human being. ${ }^{6}$ Following Aristotle, he distinguished between a nutritive power, a sensitive power, and a rational power, which appear in sequence in the human embryo. Yet in one point he parted ways with the philosopher. He claimed that the rational soul was present in the embryo from the

3 Aristotle, De anima II/1, 413a23-412b9.

4 Aristotle, De generatione animalium II.3, 736b28.

5 Arguments for inseparability can be found in the writings of the Peripatetic philosopher Alexander of Aphrodisias. By contrast, Neoplatonic philosophers stressed the independence of the highest faculty from the body, which allowed them to reconcile the views of Plato and Aristotle. See P. Moreaux, Alexandre d'Aphrodise: exégète de la noétique d'Aristote. Liège/ Paris 1942; and H.J. Blumenthal, Aristotle and Neoplatonism in late antiquity: interpretations of De anima. London 1996. Even modern historians of philosophy have not agreed on the exact meaning of Aristotle's statements. See C. SHIELDS, Aristotle, De anima, translated with an introduction and commentary. Oxford 2016, 312 -329; J.M. RIsT, Notes on Aristotle De anima 3.5. The Classical Philology 61 (1966), 8-20; L.P. GERson, The unity of intellect in Aristotle's "De anima”. Phronesis 49 (2004), 348-373; and R. Polansky, Aristotle’s De anima. Cambridge 2007, 434- 457.

6 Gregory of Nyssa, De hominis opificio. PG 44, $123-255$. See C. Scholten, Welche Seele hat der Embryo? Johannes Philoponos und die antike Embryologie. Vigiliae Christianae 59 (2005), 377-411, esp. 405-406; A. Meredith, The concept of the mind in Gregory of Nyssa and the Neoplatonists, in E. A. Livingstone (ed.), Studia patristica 22. Oxford 1989, 35-51; and S. WESSEL, The reception of Greek science in Gregory of Nyssa's "De hominis opificio". Vigiliae Christianae 63 (2009), 4-46. 
moment of conception and that it regulated the actitivy of the lower faculties, which were not part of it. ${ }^{7}$ He did not, however, go so far as to accept the Platonic concept of a pre-existent soul, which Origen had introduced into the theological discourse. ${ }^{8}$ In the twenty-eighth chapter he dealt with the question in systematic fashion. He maintained that synhyparxis was the golden mean between two diametrically opposite but equally wrong extremes, prohyparxis and methyparxis. ${ }^{9}$ According to him, those who defended the latter theory based their arguments on Genesis 2:7. ${ }^{10}$ He rejected their interpretation, arguing that if the body came first the soul would be created for the sake of the body and thus have a lower ontological status than it. ${ }^{11}$

All three positions reappear in the ensuing period of Christological controversies. For a long time, however, they were not aligned with the different camps. Theodoret of Cyrus and Eutherius of Tyana were both representatives of the 'Antiochene school'. ${ }^{12}$ In their writings they emphasised the difference between the divinity and the humanity of Christ. ${ }^{13}$ Yet they did not hold the same views about the formation of the human being. Eutherius explained that the human being was one 'because neither part has a hypostasis that precedes with-

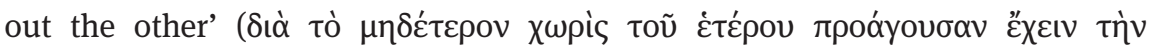

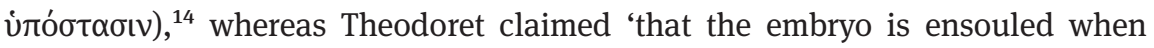

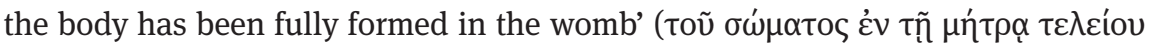

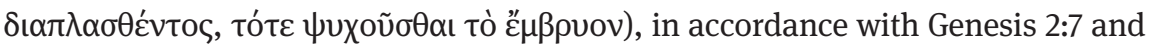
Exodus 21:22. ${ }^{15}$ The same observation can be made when we turn to the Monophysites. Philoxenus of Mabbug declared that the soul was created in the body

7 Gregory of Nyssa, De hominis opificio 29. PG 44, 237C1-D1.

8 See M.-H. CongourdeAu, L'embryon et son âme dans les sources grecques (VI siècle av. J.-C.$\mathrm{V}^{\mathrm{e}}$ siècle apr. J.-C.). Paris 2007, 96-118.

9 Gregory of Nyssa, De hominis opificio 28. PG 44, 233B4-10.

10 Ibid., 229C2-8.

11 Ibid., 229C8-D2.

12 On the notion of a 'School of Antioch', see A.M. ScHor, Theodoret's people: social networks and religious conflict in late Roman Syria. Berkeley 2011, 67-72.

13 See e.g. R. A. NorRIs, Manhood and Christ: a study in the Christology of Theodore of Mopsuestia. Oxford 1963; and P. BRUNS, Finitum non capax infiniti. Ein antiochenisches Axiom in der Inkarnationslehre Babais des Großen († nach 628). Oriens Christianus 83 (1999), $46-71$. 14 Eutherius of Tyana, Confutationes, 22; ed. M. TEтz, Eine Apologie des Eutherios von Tyana. PTS 1. Berlin 1964, 44.3-4.

15 Theodoret of Cyrus, Quaestio in Exodum 48; ed. J. F. Petruccione, trans. R.C. Hill, Theodoret of Cyrus, The Questions on the Octateuch (On Genesis and Exodus). Washingon, DC 2007, 300-301. A similar view is expressed in the treatise Graecorum affectionum curatio 5.5051; ed. P. Canivet, Théodoret de Cyr, Thérapeutique des maladies helléniques. SC, 75. Paris 1958, 243. See Congourdeau, L'embryon (as footnote 8 above), 304-305. 
forty days after the conception and referred to Exodus 21:22 and Zacharias 12:1 as proof texts. ${ }^{16}$ By contrast, Severus of Antioch, drawing his inspiration from Gregory of Nyssa, insisted that the soul and the body were created simultaneously, even though Genesis 2:7 might seem to imply a temporal sequence. ${ }^{17}$ It appears that the choice was largely determined by a person's background: 'Syrians' took a Biblicist line whereas 'Greeks' had recourse to philosophy.

All these authors rejected the view that the soul pre-existed the body. Their stance reflects an intellectual climate that became increasingly hostile to Platonising interpretations of the Christian faith. This development reached its first peak during the reign of Justinian. In 527 the emperor closed the Academy in Athens and in 553 an ecumenical council convened by him condemned the teachings of Origen and his follower Euagrius. Yet this does not mean that there were no longer dissenting voices. At this point we need to turn to Leontius of Byzantium, a Palestinian monk who was known for his Origenist leanings, and to John Philoponus, a Christian philosopher who taught in Alexandria. ${ }^{18}$ On the face of it they held mutually exclusive positions. In his treatise Contra Nestorianos et Eutychianos Leontius did not challenge the argument that body and soul were created simultaneously. By contrast, Philoponus stated in his treatise De opificio mundi that the soul appeared in the embryo after the body had been formed. Yet close reading of the texts suggests that this is not the whole story. Leontius puts forward two complementary definitions of soul and body, which reveal his philosophical allegiance. ${ }^{19}$ In the first case he speaks of an 'in-

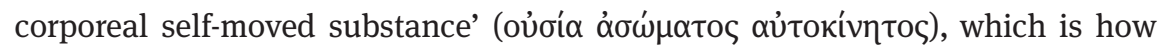
Plato's understanding of the soul is summarised in doxographical literature. ${ }^{20}$

16 Philoxenus of Mabbug, Commentary on the Prologue of the Gospel of John, quoted in Moses Bar Kepha, Liber de anima 25; trans. O. BRAun, Moses Bar Kepha und sein Buch von der Seele. Freiburg 1891, 84. On Philoxenus see most recently D. A. MicheLson, The practical Christology of Philoxenos of Mabbug. Oxford 2014.

17 Severus of Antioch, Letter to the scriniarius Simus, quoted in Moses Bar Kepha, Liber de anima, trans. BRAUN, 87 - 88. On Severus see J. LEBON, La christologie de monophysisme syrien, in A. Grillmeier / H. Bacht (eds.), Das Konzil von Chalkedon: Geschichte und Gegenwart, vol. 2. Würzburg 1951, 425-580.

18 On Leontius see D. Hombergen, The second Origenist controversy, A new perspective on Cyril of Scythopolis' monastic biographies as historical sources for sixth-century Origenism. Rome 2001, 133-138. On Philoponus see the articles in R. SoRABJI (ed.), Philoponus and the rejection of Aristotelian science. $2^{\text {nd }}$ ed. London 2010.

19 Leontius of Byzantium, Contra Nestorianos et Eutychianos; ed. B.E. DALEy, Leontius of Byzantium: Complete Works. Oxford 2017, 136.11-12.

20 Leontius of Byzantium, Contra Nestorianos et Eutychianos 2; ed. DALEy, 138.1-2. Cf. Pseudo-Galen, Definitiones medicae 29; ed. K.G. KüHN, Galeni opera omnia, 19. Leipzig 1830, 355.11-12. 
In the second case he uses the formula 'natural instrumental body that has life in

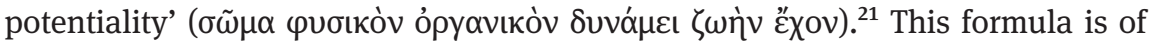
Aristotelian provenance. It is, however, a definition not of the body but of the soul, which is characterised as 'first entelechy of a natural instrumental body

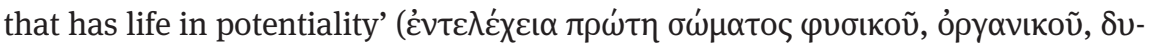

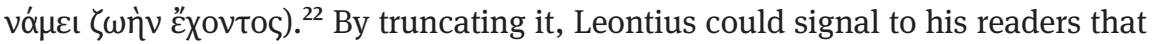
he wished to replace the Aristotelian inseparable soul with the Platonic separable one. For Plato the soul existed not only after the separation from the body but also before its union with it. This raises the possibility that Leontius, too, accepted the pre-existence of souls. Indeed, the passage contains other features, which suggest as much. He claims that he will employ the anthropological paradigm exclusively in order to illustrate 'that the Word is united with the body from

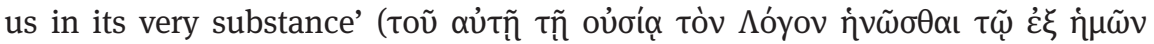
$\sigma \omega \dot{\mu} \mu \tau \tau) .{ }^{23}$ This is an unusual characterisation of the incarnation since it only considers one part of the human compound. Instead one would have expected

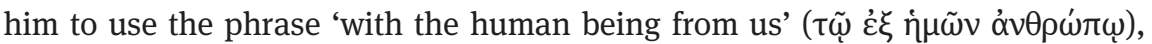
which would also have included the soul. ${ }^{24}$ The following argument is equally odd. Leontius tells us that both the Word and the soul are invisible and immortal 'even though our soul and the Word come to be in a visible and mortal body'

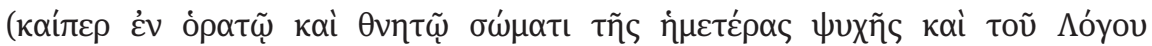

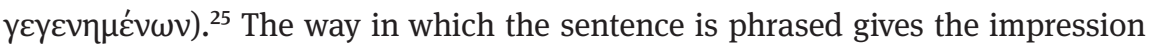
that not only the Word but also the soul is already existent when it appears in the body. ${ }^{26}$ Since Leontius picks his terminology with great care these features must be considered significant.

When we turn to Philoponus we seem to enter a different world. He concludes from Genesis 2:7 and Exodus 21:22 that ensoulment only takes place after the body has been fully formed. ${ }^{27}$ Yet Scriptural proof texts are clearly of secondary importance to him. His argument is largely derived from the philo-

21 Leontius of Byzantium, Contra Nestorianos et Eutychianos 2; ed. DALEY, 138.5 -6.

22 Aristotle, De Anima II/1, 412a27-8.

23 Leontius of Byzantium, Contra Nestorianos et Eutychianos; ed. DALEY, 136.15-16.

24 If he had used the term 'flesh' ( $\sigma \alpha \alpha \rho \xi)$ he would have made a much less explicit statement, since according to Patristic tradition it denoted the compound of body and soul.

25 Leontius of Byzantium, Contra Nestorianos et Eutychianos 2; ed. DALEY, 136.20-21.

26 Significantly, he uses the same verb in both cases. Thus he downplays the difference between the eternal Word and the soul, which most Christians regarded as a created being.

27 John Philoponus, De opificio mundi VI/25; ed. G. REICHARDT, Johannis Philoponi de opificio mundi libri VII. Leipzig 1897, 280.12-281.18. 
sophical discourse. ${ }^{28}$ With Aristotle, he declares that the formation of the embryo is the task of the nutritive soul. ${ }^{29}$ Yet his reading of Aristotle is heavily influenced by Platonic notions. He distinguishes between two types of entelechy, one that is inseparable and one that is separable from the body. ${ }^{30}$ This allows him to safeguard the immortality of the rational soul. In his treatment he repeatedly rejects synhyparxis, with the argument that the rational soul would then also disappear with death, as is the case with animals. ${ }^{31}$ This is a rather odd line of reasoning. A closer look suggests that one further aspect needs to be taken into account. Philoponus does not say that the rational soul is created in the pre-existing body but that it is infused into it, which is a clear reference to the Aristotelian 'intellect from the outside' ( $\theta \dot{\prime} \rho \alpha \theta \varepsilon v$ voũ $)$. What this means for the soul can be seen from the following statement: 'But the soul of human beings has come to be from a different origin, for having a substance that is separable from the bodies, it is infused into them from the outside after the formation ... and for this reason it is again (!) separated when (sc. the body) is corrupted and is not equally dis-

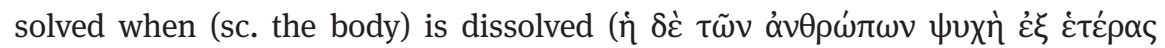

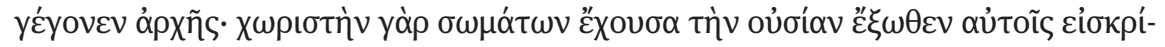

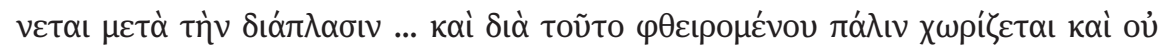

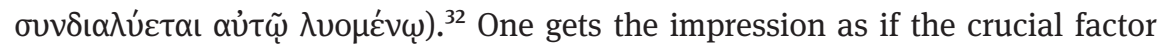
is not the pre-existence of the body but the pre-existence of the soul. This does not mean that Philoponus is an Origenist for he claims that 'no ... rational

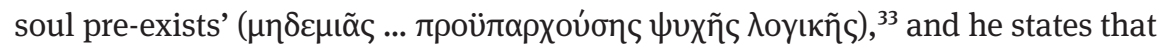
the souls of human beings came into existence 'after the coming-to-be of the

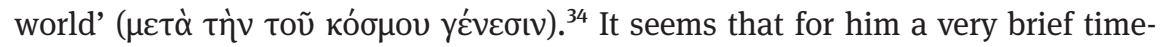
span was sufficient to ensure the separability of the soul. ${ }^{35}$

Leontius and Philoponus had to tread carefully because they might have been accused of Origenism. By contrast, there is no evidence for polemic between the champions of the other two opinions. Eutherius and Theodoret on

28 See Scholten, Seele (as footnote 6 above), 378-395, who compares De opificio mundi with Philoponus' philosophical works. Discussion of this topic would go beyond the scope of this paper. See also the brief remarks in CongourdeAu, L'embryon (as footnote 8 above), 332. 29 John Philoponus De opificio mundi VI/24; ed. REICHARDT, 277.24.

30 Ibid., 277.21-278.13.

31 John Philoponus De opificio mundi VI/23; ed. REICHARDT, 276.14-17.

32 Ibid., 276.23-26.

33 John Philoponus, De opificio mundi VII/3; ed. REICHARDT, 287.27-30.

34 John Philoponus, De opificio mundi, I/11; ed. REICHARDT, 26.21-27.6.

35 Scholten, Seele (as footnote 6 above), 396, concludes that Philoponus was a creatianist. This is certainly true but it does not invalidate the 'brief' pre-existence proposed here. 
the one hand, and Philoxenus and Severus on the other evidently did not consider the topic to be of such importance that they felt the need to inveigh against each other. This irenic attitude, however, was not to last forever.

In the first half of the sixth century Nestorians could still hold the view that soul and body are created at the same time. In Leontius of Byzantium's treatise Contra Nestorianos et Eutychianos a Nestorian interlocutor claims that the human being cannot be used as an analogy for the incarnated Word because the Word pre-exists the flesh whereas in it 'neither of the parts has its being without the other'

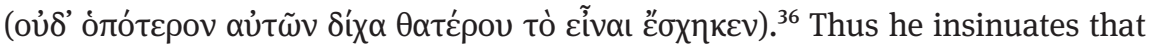
the position of the Chalcedonians is inconsistent. If their Christology is correct and they nevertheless wish to use the anthropological paradigm they can only meaningfully do so when they accept that the soul, too, pre-exists the body. From the argument it is clear that synhyparxis is regarded as a 'safe option', which rules out an Origenist understanding of the soul. By the end of the century the situation had changed radically. In his Liber de unione Babai the Great, a Nestorian monk who had studied at the School of Nisibis and was well versed in speculative theology, claimed that the soul was created in the embryo forty days after conception, in accordance with Exodus 21:22 and Genesis 2:7,37 and that up to that point the body grew like a plant or a zoophyte, ${ }^{38}$ a view that may owe something to Aristotle. He regarded it as impossible that a soul could be present in a body that was not yet fully formed, and supported his contention with the argument that damage or loss of vital organs forced the soul to leave its receptacle. ${ }^{39}$ This in itself would not be surprising. As we have seen Theodoret had been of the same opinion. Yet Babai then launches into a blistering attack against those who accepted the notion of synhyparxis.

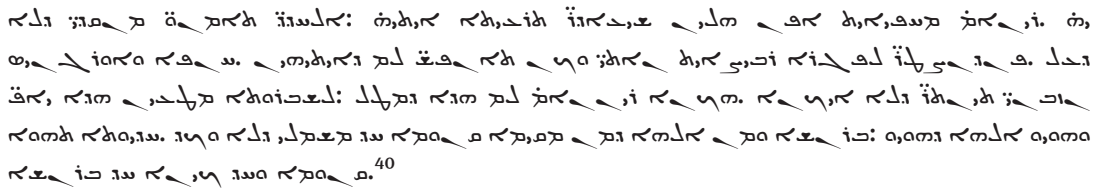

36 Leontius of Byzantium, Contra Nestorianos et Eutychianos 2; ed. DALEY, 134.21-23.

37 Babai of Nisibis, Liber de unione X, trans. A. VASCHALDE, Babai Magni liber de unione, 2. Corpus Scriptorum Christianorum Orientalium, 80. Rome/Paris 1915, 90.1, 94.23.

38 Ibid., 94.26-30. See also Appendix, 235.16-18.

39 Ibid., $89.24-32$.

40 Babai of Nisibis, Liber de unione, X; ed. A. VAschalde, Babai Magni liber de unione, 1. Corpus Scriptorum Christianorum Orientalium 79. Rome / Paris 1915, 109.15-22. 
That one part does not precede the other is the opinion of those wicked ones, even if they express themselves obscurely, and of Origen the pagan, that <first > were the souls and that they then came by force into the bodies and were afflicted. And because of that they deceive the children, <saying $>$ : We say thus in order that the union does not happen twice, and when one stable hypostasis from God and the human being is not completed, for the same is God and the same is human being, one nature and one hypostasis. ${ }^{41}$

Here it is claimed that whoever speaks of synhyparxis in reality holds the view that the soul pre-exists the body. This rather surprising shift is the consequence of two developments, a heightened awareness of the Christological implications of the different options and an even more aggressive attitude towards Origenists. ${ }^{42}$ Chalcedonian and Monophysite theologians felt that they had to opt for synhyparxis in the case of Christ because otherwise they could not uphold their belief that the incarnation resulted in one hypostasis or nature. Once the Nestorians realised this fact they pounced on their adversaries, arguing that in the ordinary human being the body preceded the soul and that this must then also be true for Christ's humanity, since according to Hebrews 4:15 he was like us in all respects apart from $\sin .^{43}$ They themselves could hold such a view because they believed that the divine Word and the human being Jesus were separate hypostases even after the union. This does not, however, mean that for Nestorians everything was plain sailing. Two options presented themselves to them: either the Word united itself first with the body and then with the soul, or the union only happened when the soul appeared. Babai ruled out the second option because he thought that it would run counter to the account of the Annunciation. ${ }^{44}$ Indeed, for him it was little better than adoptionism. ${ }^{45}$ Accordingly, he had to explain why there were not two successive unions with the Word, first of the body and then of the soul. His solution was to maintain that it was in both cases the Word that effected the union. ${ }^{46}$

Babai who wrote his treatises in Syriac lived in the Persian Empire. Yet this does not mean that Nestorianism had disappeared from Greek-speaking milieus inside the Roman Empire. In the late sixth or early seventh century an anonymous Nestorian author wrote a Christological treatise against Chalcedonians

41 I would like to thank Grigory Kessel and Nicolás Bamballi for translating this passage. 42 See D. Krausmüller, Origenism and anti-Origenism in the late sixth and seventh centuries, in J. Kalvesmaki / R.D. Young (eds.), Evagrius and his legacy. Notre Dame, Indiana 2015, 288 316.

43 Babai of Nisibis, Liber de unione, $\mathrm{X}$, tr. VASCHALDE, 86.20.

44 Ibid., $86.13-16$.

45 Ibid., 82.34-83.7.

46 Ibid., 92.13-21. 
and Monophysites, which is partially preserved as quotations in Leontius of Jerualem's Contra Nestorianos. ${ }^{47}$ This author started from the same premises as Babai but came to a different conclusion.

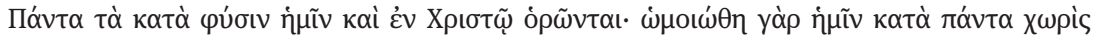

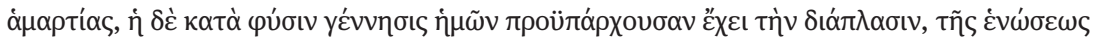

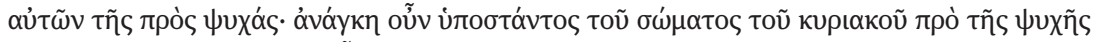

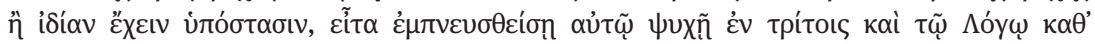

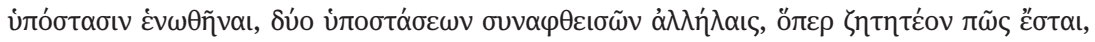

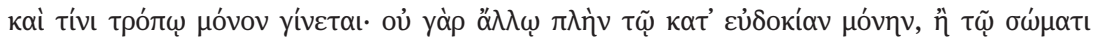

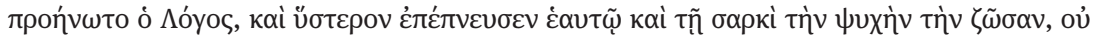

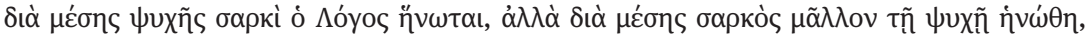

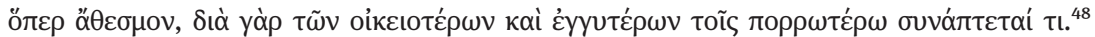

Everything that belongs to our nature is also seen in Christ, for he became like us in all respects apart from sin, but our begetting according to nature is such that the formation (sc. of the bodies) exists before their union with the souls. It is, then, necessary when the lordly body gained hypostasis before the soul, (1) either that it had its own hypostasis, and was hypostatically united with the soul that was breathed into it in third place, and with the Word, so that two hypostases were connected with one another, in which case one must ask how this could be, and in what manner it can happen only, for it is possible in no other way than in the manner according to good pleasure, (2) or that the Word was first united with the body and afterwards breathed into himself and into the flesh the living soul, in which case the Word was not united with the flesh through the mediation of the soul, but rather was united with the soul through the mediation of the flesh, which is illicit, because something is connected with the things that are further removed from it through the things that are more familiar and closer.

Like Babai, the anonymous author bases his argument on Hebrews 4:15. He avers that in ordinary human beings the body precedes the soul and that the same must then also be true for Christ's humanity. Moreover, he accepts that the union can only have happened once. Yet then the arguments diverge. The anonymous author rejects the solution proposed by Babai, and instead claims that the incarnation only took place when the soul was created. This means that the body existed independently before the union, a position, which the anonymous author does not find problematic because for him the union only estab-

47 See D. KRaUSmüLleR, Leontius of Jerusalem, a theologian of the 7th century. The Journal of Theological Studies 52 (2001), 637 -657. See also P.T. R. GRAY, Leontios of Jerusalem, Against the Monophysites. Testimonies of the Saints and Aporiae. Oxford 2006, who argues for an earlier date.

48 Leontius of Jerusalem, Contra Nestorianos II/20. PG 86, 1580C4-D6. 
lishes a loose relationship of good pleasure. ${ }^{49}$ Fortunately for us, he takes the trouble to explain why the alternative needs to be ruled out. He states that the union of body and divinity had to be established through the soul because it

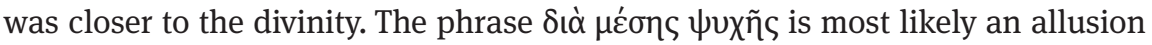
to a famous statement of Gregory of Nazianzus: 'The uncontainable is contained through the mediation of the intelligible soul, which mediates between the divin-

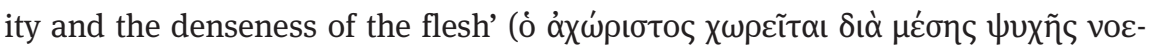

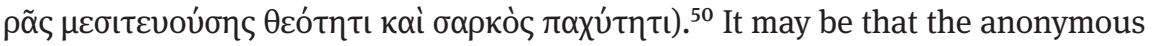
author only formulated his argument in this way because Chalcedonians (and possibly also Monophysites) referred to Gregory's dictum in order to exclude the scenario sketched by Babai.

Interestingly, in his response Leontius of Jerusalem does not speak about these conceptual problems but rather rejects the anonymous author's premise.

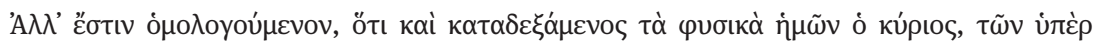

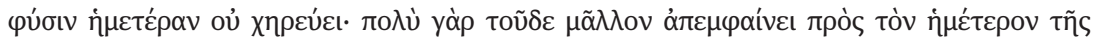

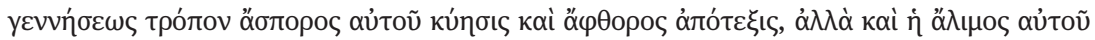

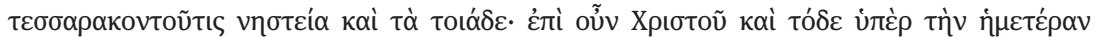

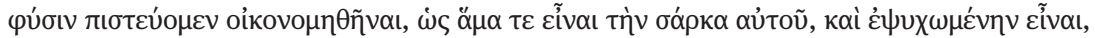

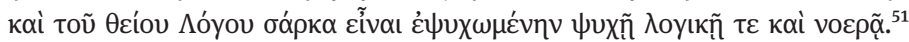

But it is agreed that the Lord, even though he assumed our natural properties, was not bereft of the properties that are beyond our nature, for his conception without semen and birth without corruption was rather much more different from the manner of our begetting, but also his fasting for forty days without feeling hungry and other such things. In the case of Christ, then, we believe this, too, to be arranged beyond our nature, that simultaneously his flesh comes into being, and is ensouled, and that the flesh of the divine Word is ensouled with a rational and intellectual soul.

Instead of claiming that in ordinary human beings body and soul come into existence at the same time and that this is then also the case with the incarnation, Leontius questions the relevance of Hebrews 4:15 for the discussion. He points out that Christ's humanity differed from other human beings not only through sinlessness but also through the conception without semen, and the birth without corruption. This then permits him to claim that synhyparxis is just one further supernatural feature in Christ's life.

49 On this notion see F.G. McLeod, Theodore of Mopsuestia revisited. Theological Studies 61 (2000), $447-480$, esp. $469-471$.

50 Gregory of Nazianzus, Oratio 38.13; ed. C. MoRESCHINI, Grégoire de Nazianze, Discours 38 41. SC, 358. Paris 1990, $134.37-40$.

51 Leontius of Jerusalem, Contra Nestorianos II/20. PG 86, 1580D7-1581A3. 
Leontius' willingness to accept the anonymous author's view about the ensoulment of the embryo shows that this view was not only held by Nestorians. Indeed, several of his own arguments are based on this conceptual framework. At one point the anonymous author claims that Mary should not be called Godbearer because a human being can only give birth to a human being. Leontius responds by claiming that this is not even the case with ordinary human beings.

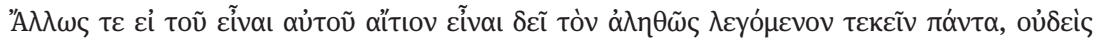

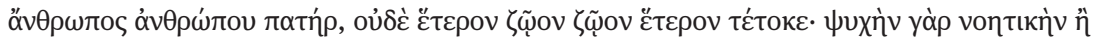

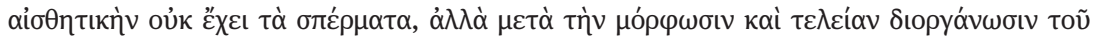

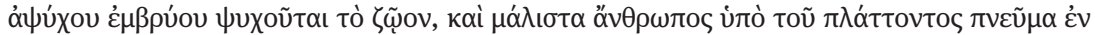

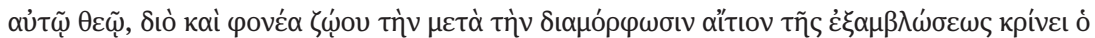

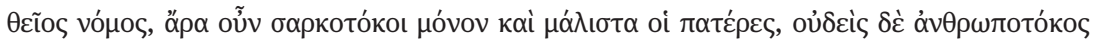

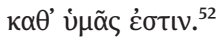

Furthermore, if it is necessary that the one who is truly said to be cause of the being of it must beget all, no human being would be a father of a human being, nor would one living being have begotten another living being, for the semen does not have the intelligible and sensitive soul, but the living being, and especially the human being, is ensouled after the formation and complete organisation of the soulless embryo, by God who forms the spirit in it, wherefore the divine law judges the one who causes a miscarriage after the formation to be the murderer of a living being, it follows that the fathers in particular are only begetters of flesh and nobody would be a begetter of a human being according to you.

Here Leontius accepts the view that the soul only appears when the body is fully formed, and even adds a reference to Exodus 21:22. The allusion to Zachariah 12:1 gives the impression that like Babai, he believed the soul to be created. Yet other passages suggest that this is not the entire story. When discussing Genesis 2:7 he states that 'the divine inbreathing was united in a hypostasis with the body of

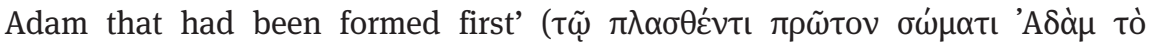

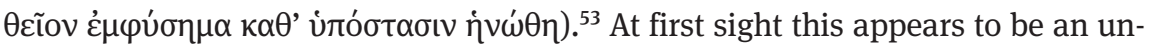
equivocal reference to methyparxis. The statement is, however, less clear-cut than it first seems. In this case Leontius does not say that Adam's soul was created in the pre-existing body. He merely speaks of the endowment of Adam's body with the soul. Moreover, he rephrases the Biblical verse in such a way that it corresponds to traditional definitions of the human being as 'the soul ... that has

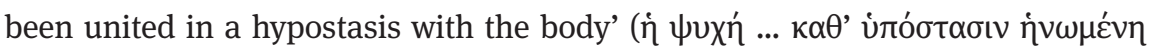

52 Ibid., 1681B15-C11.

53 Ibid., 1493B5 - 7. 
$\tau \tilde{\omega} \sigma \omega \dot{\omega} \mu \alpha \tau \iota) .{ }^{54}$ The obvious consequence of this reformulation is the replacement

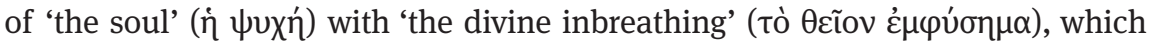
sends a clear signal to the readers that these two terms refer to one and the same reality. I have discussed this statement and other passages where the term appears in a recent article. From Leontius' equation of divine inbreathing and di-

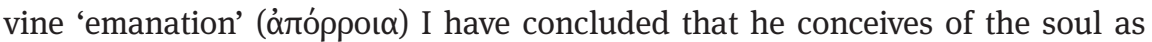
a pre-existing entity, which had been in God. ${ }^{55}$ If this interpretation is correct Leontius would have opted for a position that was considered strictly anti-Origenist but only in order to manipulate it in such a way that it allowed for an Origenist reading. Such a scenario presupposes that methyparxis was also widely accepted in Chalcedonian circles. That this was indeed the case can be seen from a passage in the Ambigua of Maximus the Confessor who flourished in the first half of the seventh century. ${ }^{56}$

Maximus opens the discussion with a rhetorical strategy that had already been used by Gregory of Nyssa. He presents synhyparxis as the happy medium between prohyparxis and methyparxis as two diametrically opposed but equally wrong extremes. The discussion of prohyparxis has repeatedly been the subject of scholarly enquiry. There Maximus rejects Origen's notion of a monad of preexisting minds that entered their bodies at a later stage and instead sets out his own teaching about the eternal 'reasons' ( $\lambda$ óyou) in God. ${ }^{57}$ By contrast, the discussion of methyparxis has elicited less interest. ${ }^{58}$ Yet it was clearly of great importance to Maximus. Only here does he directly address his adversaries as

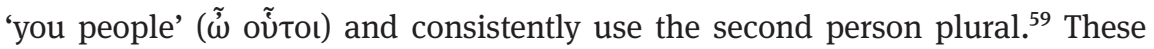
are clear signs that he intervened in a contemporary debate. Maximus claims that it is easy to speak of methyparxis but that deeper engagment reveals concep-

54 See e.g. Anastasius the Sinaïte, Capita vi adversus monotheletas 9.1; ed. K.-H. UthemanN, Anastasii Siinaitae sermones duo in constitutionem hominis secundum imaginem Dei necnon opuscula adversus monotheletas. CC, Series Graeca 12. Turnhout 1985, 137.1-2.

55 D. KRAUSmÜlLER, Human souls as consubstantial Sons of God: The heterodox anthropology of Leontius of Jerusalem. Journal of Late Antique Religion and Culture 4 (2010), $43-67$.

56 There is a substantial literature on Maximus' life and teachings. See most recently the contributions in P. AlLEN / B. NeIl (eds.), The Oxford Handbook of Maximus the Confessor. Oxford 2015.

57 See the seminal work of P. SHERwood, The earlier Ambigua of St Maximus the Confessor and his refutation of Origenism. Rome 1955; see also A. Louth, Maximus the Confessor. London/ New York 1996, 65-68.

58 See esp. M.-H. Congourdeau, L'animation de l'embryon humain chez Maxime le Confesseur. Nouvelle revue théologique 111 (1984), 693-709.

59 Maximus, Ambigua ad Johannem. $P G$ 91, 1336C3-4, 1337B3-5. 
tual problems. ${ }^{60}$ At first he states that a body without a soul is dead and that it was therefore impossible for the embryo to grow prior to its ensoulment. ${ }^{61}$ This is indeed a problem that arises when the case for methyparxis is exclusively made on the basis of Scripture. Yet by Maximus' time the champions of methyparxis had long moved beyond this point. They made use of Aristotelian concepts, declaring that the embryo was fashioned first by the nutritive soul and then by the sensitive soul, before the rational soul appeared. Maximus ridicules this conceptual framework, claiming that human beings would then be parents of plants and animals. ${ }^{62}$ Then he turns to another opinion, which does not seem to be attested elsewhere. According to him some people were worried that the rational soul would be somehow involved in the messy business of conception and therefore concluded that it would only be infused forty days later. ${ }^{63}$ Biblical proof texts play a subordinate role in Maximus' treatment. Only once does he refer to Exodus 21:22 on which the champions of methyparxis built their argument. He claims that the verse does not refer to the entering of the soul but to the formation of the body. ${ }^{64}$ This is a rather lame argument since it does not explain why the one responsible for a miscarriage in early pregnancy only has to pay a fine. ${ }^{65}$

In the last part of his discussion Maximus considers the implication of the different models for the incarnation. He explains that there was no interval between the coming-to-be of the body and the coming-to-be of the soul and that 'the Lord was united with the flesh through the mediation of the rational soul'

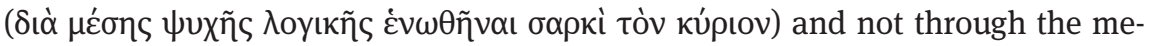
diation of a soulless body. ${ }^{66}$ This statement bears a striking similarity to the argument of the anonymous Nestorian, which shows clearly that we are dealing with the same discourse. Yet Maximus' adversaries were undoubtedly Chalcedonians. Had they belonged to a different Christological sect he would not have hesitated to point it out. Indeed, it appears that Maximus responded to people who shared the views of Leontius of Jerusalem.

60 Ibid., $1336 \mathrm{C} 3-7$.

61 Ibid., $1336 \mathrm{C} 7-1337 \mathrm{~B} 3$.

62 Ibid., 1337B3-D4.

63 Ibid., 1340B1-C5.

64 Ibid., 1340D4-1341A1.

65 Philoponus ridiculed this interpretation, see John Philoponus, De opificio mundi VI/25; ed. REICHARDT, 280.12-281.18.

66 Maximus, Ambigua ad Johannem. PG 91, 1341A13-14. 


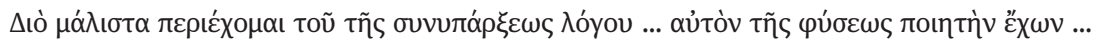

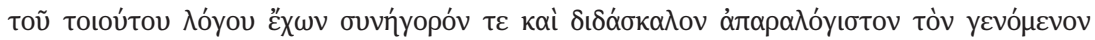

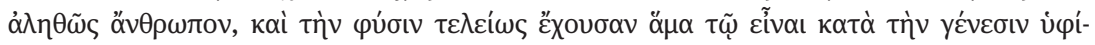

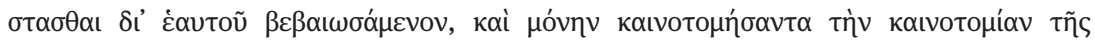

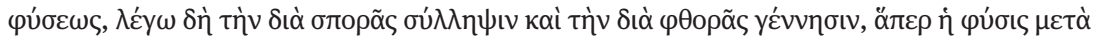

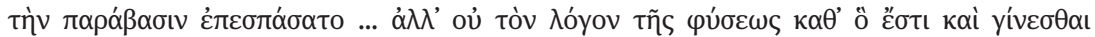

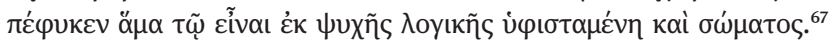

Therefore I most of all hold fast to the concept of simultaneous existence ... having the maker of nature himself ... as an advocate and undeceived teacher of such a concept, who truly became a human being, and made sure through himself that the nature gains hypostasis as one that is complete simultaneously with its being in respect of coming-to-be, and who only innovated two things in nature, that is, the conception through semen and the birth through corruption, which the nature acquired after the fall ... but not the account of nature, according to which it is and comes to be by nature, simultaneously with its being, as being constituted from a rational soul and a body.

This statement is immediately followed by a passage that rules out 'innovation'

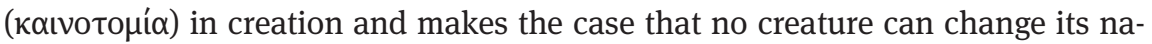
ture, which defines what it is. ${ }^{68}$ It has often been discussed but without consideration of the specific context in which it is found. ${ }^{69}$ Maximus sets himself the task to show that there is a strict parallelism between Christ's humanity and ordinary human beings. He claims that synhyparxis is required by the 'account of

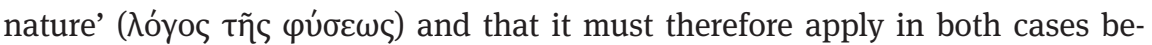
cause otherwise Jesus would not be in all respects like us apart from sin. Yet he does admit that there are two exceptions, the conception and birth of Christ, which weaken his argument considerably. As we have seen Leontius of Jerusalem claims that these are supernatural events, which limit the significance of Hebrews 4:15, and that it is therefore entirely conceivable that synhyparxis is also a supernatural trait. Maximus has to exclude this option at all costs. He does

67 Ibid., 1341B6-C7.

68 Ibid., 1341D1-1345A5.

69 See J.-M. Garrigues, Maxime le Confesseur. La Charité, avenir divin de l'homme. Paris 1976, 103 -104; L. THUNBERG, Microcosm and mediator: the theological anthropology of Maximus the Confessor. Chicago 1995, 417, J.-C. LARCHET, La divinisation de l'homme selon Maxime le Confesseur. Paris 1996, 144-145, 265-266, 347 -355, 606-607; D. SkLIRIs, "Hypostasis", "person", "individual", "mode": a comparison between the terms that denote concrete being, in M. Vasilievich (ed.), Knowing the purpose of everything through the Resurrection. Proceedings of the Symposium on St Maximus the Confessor, Belgrade, October 18-21, 2012. Alhambra, CA / Belgrade 2013, 437-450, esp. 447; and A. LouTH, St. Maximos' distinction between 入óyos and тро́лоৎ and the ontology of the person, in S. Mitralexis / G. Steiris / M. Podbielski / S. Lalla (eds.), Maximus the Confessor as a European philosopher. Eugene, OR 2017, 157-164. 
so by claiming that the conception through semen and the birth through corruption were not originally part of human nature but were only introduced into it after the fall. ${ }^{70}$ Maximus' adversaries were most likely driven by anti-Origenist concerns. ${ }^{71}$ For them, as for Babai, synhyparxis in ordinary human beings would have opened the door for prohyparxis and thus for the Origenist heresy. Maximus' rejection of prohyparxis may have had the function to show that this was a baseless fear.

Maximus' life-time was a period of dramatic political change. In the 630s and 640s the Eastern provinces of the Roman Empire were lost to the Arab invaders. Once the Muslim Caliphate had been established all three Christological sects flourished and many theological works were produced. This raises the question: did the debate about the ensoulment of the embryo also continue? In the case of the Chalcedonians or Melkites the evidence is slight. In the later seventh century the monk Anastasius of Sinai wrote two sermons about the divine image. ${ }^{72}$ In the former text he lists the different options, rejecting prohyparxis as heretical but mentioning synhyparxis and methyparxis without comment. ${ }^{73}$ In the latter text he claims that only synhyparxis is correct. He comes to this conclusion because he has a particular understanding of the divine image in the human being. He believes that Adam was created in the image of the incarnated Word. Since in the case of Christ the components appeared simultaneously the same must apply to the conception of ordinary human beings. ${ }^{74}$ Later authors show even less interest in the question. In the first half of the eighth century John of Damascus, a former Caliphal administrator who had become monk in Palestine, declares in his Expositio fidei that soul and body are created at the same time. But he then only rejects prohyparxis as a heretical opinion. ${ }^{75}$ Methyparxis as a third option is not even considered. Gregory's opinion that the soul must mediate between God and the body is mentioned but without reference to an alternative view. ${ }^{76}$ Even in John's anti-Nestorian treatises the topic is not discussed. There

70 See Thunberg, Microcosm, ibid., 160.

71 See G. BENEvich, Maximus Confessor's polemic against anti-Origenism. Revue d'histoire ecclésiastique 104 (2009), 5-15, who focuses on Maximus' sixth and seventh letters. In these cases it is clear that Maximus' opponents are Chalcedonians.

72 For the following see CongourdeAu, L'embryon (as footnote 8 above), 333-334.

73 Anastasius of Sinai, Sermo I/2; ed. Uthemann (as footnote 54 above), 14.21-16.41.

74 Ibid., $40.34-41.47$.

75 John of Damascus Expositio fidei 26; ed. B. KoTTER, Die Schriften des Johannes von Damaskos, 2. PTS, 12. Berlin 1973, 76.22-23.

76 John of Damascus, Expositio fidei 46, 50; ed. KotTER, 109.16-23; 121.31-32. 
we only find the banal statement that the humanity does not pre-exist the union. ${ }^{77}$ When we turn to Theodore Abu Qurrah, the bishop of Carrhae, who flourished in the late eighth and early ninth century we find that the situation is not much different. In his opuscula Theodore only says that the Word assumed an ensouled body into his hypostasis. ${ }^{78}$

This silence is rather peculiar since members of the other two camps continued to discuss the topic. In the late eighth century the Nestorian Theodore Bar Koni, a teacher of Scripture, explained in his Book of Scholia that the soul was created after the body. ${ }^{79}$ His contemporary, patriarch Timothy I (780-823), a highly learned man who exercised his function in Baghdad, the new capital of the Caliphate, spelt out the Christological implications of this view. In a letter to the Christians of Basra he explained that the Evangelist John said 'the Word became flesh' but not 'the Word became a human being' since he united himself first with the body alone, at the moment of conception, and only after forty days with the soul as well, just as it is the case with ordinary human beings. In order to support this view he pointed out that body and soul were also separately united with the Word during the three days between death and resurrection. ${ }^{80}$ This is in keeping with Babai's position, which suggests that the alternative explanation of the anonymous Nestorian author was considered to be too extreme.

In order to explain how the body is formed without a soul Timothy had recourse to Aristotelian philosophy. He distinguished the nutritive and sensitive powers from the rational soul that was created later. ${ }^{81} \mathrm{He}$ thus was of the same mind as Maximus' Chalcedonian adversaries. Interestingly, this conceptual framework also appears in the writings of Monophysite authors. One of their number, Jacob of Edessa, a learned monk who flourished in the early eighth century, rejected prohyparxis and methyparxis. In a letter to the stylite John of Litarba he declared that both options were heretical, the former because it was defended by Origen, and the latter because it implied that the soul was created

77 John of Damascus, Contra Nestorianos; ed. B. KotTER, Die Schriften des Johannes von Damaskos. PTS, 22. Berlin 1981, 286.22-31.

78 Theodore Abu Qurrah, Opusculum 11, trans. J.C. LAMOREAUx, Theodore Abu Qurrah. Library of the Christian East, 1. Provo, Utah 2005, 131. See also IDEM, The biography of Theodore Abu Qurrah revisited. DOP 56 (2002), 25-40.

79 See V. BERTI, L'au-delà de l'âme et l'en-deçà bu corps. Approches d'anthropologie chrétienne de la mort dans l'Église syro-orientale. Paradosis, 57. Fribourg 2015, 103, note 366. 80 Timothy I, Epistula 34, 108. For a more detailed discussion see BERTI, ibid., 102-109. 81 Theodore Bar Koni, Book of Scholia II/54, trans. R. HeSPEL / R. DraguET, Theodore Bar Koni, Livre des scolies (recension de Seert), I. Mimre I-V. CSCO, 431. Leuven 1981, 100. Cf. BERTI, L'au-delà, 73-102. 
for the sake of the body and thus ontologically inferior, an argument that we have already encountered in Gregory of Nyssa's De hominis opificio. Yet he does acknowledge the existence of the nutritive and sensitive powers. Unlike Gregory, he considers them to be parts of one single soul, which gradually unfolds itself. That he should engage with Aristotle is not surprising since he was familiar with the philosopher's works. ${ }^{82}$

In the later ninth century another Monophysite author, Moses Bar Kepha, inserted Jacob's text into his Liber de anima. There it is part of an extensive discussion of the question. Moses who was extremely well-read starts the discussion with a historical overview. He explains that originally there had been no agreement among 'Syrian' and 'Greek' Monophysites since the former tended to opt for methyparxis and the latter for synhyparxis. ${ }^{83}$ Yet he makes it clear that for a Monophysite of his generation only synhyparxis was acceptable, no doubt for Christological reasons. ${ }^{84}$ Then he launches into a debate with the defenders of prohyparxis and methyparxis. In the latter case exegesis of Scripture is again at the centre. Moses explains that Genesis 2:7 does not imply a temporal sequence and that Exodus 21:22 concerns itself alone with the formation of the body and not with the soul, an argument that we have already encountered in Maximus. ${ }^{85}$ In the second step he then strives to show that methyparxis leads to absurd consequences. He claims that death involves both body and soul, which are separated from one another, and that at the conception both body and soul must also be present, since beginning and end must correspond to one another. Moreover, he avers that if one accepted methyparxis the human being would at first not be a human being and only later become one, which is impossible because one and the same being cannot be itself and its exact opposite. ${ }^{86}$

One can ask why Monophysites and Nestorians continued to debate the issue whereas the Melkites did not. One possible answer is that in Iraq members of the former two sects lived side by side and had to defend their positions against one another. By contrast, Melkites who were strongest in Western

82 Jacob of Edessa, Letter to John of Litarba, quoted in Moses Bar Kepha, Liber de anima 25, trans. BRAUn, 88. See J.J. van Ginkel, Greetings to a virtuous man: the correspondence of Jacob of Edessa, in B. ter Haar Romeney (ed.), Jacob of Edessa and the Syriac culture of his day. Leiden / Boston 2008, $67-82$, esp. $78-79$.

83 Moses Bar Kepha, Liber de anima, ibid., 83-88.

84 Ibid., 88-89.

85 Ibid., 92-93.

86 Ibid., $93-94$. 
Syria and Palestine may have lived in a confessionally more homogeneous world. ${ }^{87}$

The texts that we have analysed reflect the lively intellectual climate in the Caliphate. Evidence for Byzantium is more limited. Intellectual activity was largely restricted to the capital Constantinople. There we have no evidence for continuous engagement with the topic. In the eighth and early ninth century the theological debate focused on a single issue, the veneration of images. Topics that had no bearing on it were not discussed. The situation only changed in the second half of the ninth century. In his Amphilochia the learned Patriarch Photius (858-867, 877-886) offers an exegesis of Exodus 21:22. Surprisingly he claims that this verse and Genesis 2:7 are evidence for methyparxis. What he has to say, however, turns out to be a literal quotation from Theodoret of Cyrus. ${ }^{88} \mathrm{~A}$ more considered treatment is found in a treatise against the heresy of the Theopaschites, which targets the Monophysite Armenians. ${ }^{89}$ There Photius argues that the human compound is not a suitable paradigm for the incarnated Word. In this context he makes the following statement.

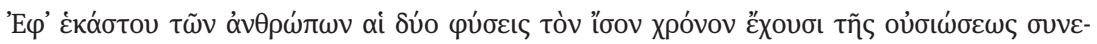

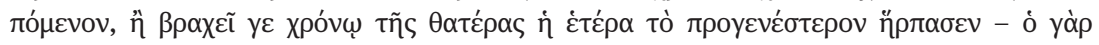

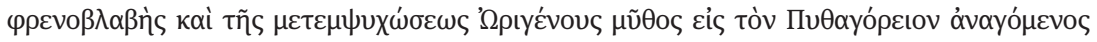

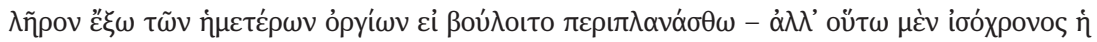

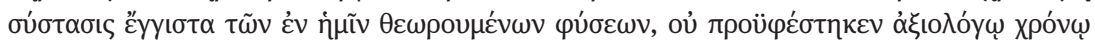

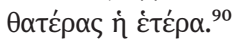

In the case of each of the human beings the two natures have the simultaneity of substantiation as a corollary, or one has snatched priority over the other by a brief time - for Origen's deranged myth of the transmigration of souls, which is derived from the blather of the Pythagoreans, may stray outside our rituals if it so wishes - but the constitution of the natures that are seen in us is virtually simultaneous, one does not pre-exist the other for a considerable amount of time.

87 There is scant evidence for the presence of Nestorians in these regions and there was no disagreement with the Monophysites who did live there.

88 See Photius, Amphilochium 267; ed. L.G. WeSterink, Photii patriarchae Constantinopolitani epistulae et amphilochia VI/1. Leipzig 1987, 58.2-8.

89 On this dispute see I. Dorfmann-Lazarev, Arméniens et Byzantins à l'époque de Photius: deux débats théologiques après le Triomphe de l'Orthodoxie. CSCO, Subsidia, 117. Leuven 2004. 90 Photius Epistula 284; ed. B. LAOURDAs/L.G. Westerink, Photii patriarchae Constantinopolitani epistulae et amphilochia, 3. Leipzig 1985, 22.673-679. 
This statement is immediately followed by the Christological application. Photius points out that the divine Word existed from eternity. The claim that the soul comes into existence together with the body whereas the Word pre-exists the flesh is already found in Maximus' writings. Yet Photius introduces a significant modification. He claims that the soul is created shortly before the body. ${ }^{91}$ In order to forestall criticism he condemns Origenism. We are not told why it was so important to affirm the soul's pre-existence. It is possible that Photius agreed with Philoponus that the soul had to exist on its own even if only for a very brief timespan in order to ensure that it could continue to exist after its separation from the body. What is missing is a discussion of the Christological implications. Does the Word first unite with a human soul and then with a human body? We do not know how Photius dealt with this problem or whether he was even aware of it.

The issue is discussed in much greater depth in a short treatise by Arethas (d. c. 944), the metropolitan of Caesarea, a very learned man, who played an important role in the ecclesiastical politics of the time. ${ }^{92}$ According to the proem it was composed after a discussion with the monk Nicetas the Paphlagonian, a well-known author of encomia in honour of saints, who was equally belligerent. ${ }^{93}$ It is written in fiendishly difficult Greek, which poses considerable problems to the understanding. The first argument, which according to the pinax was directed 'against Aristotle and those who say that in the womb the embryo is provided for

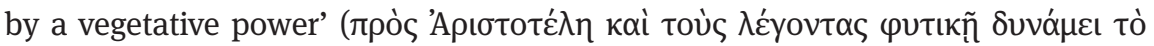

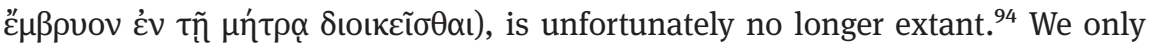
have the last paragraph where Arethas pokes fun at those who claim that at the beginning there is only a nutritive soul. He points out that if one assumed that a plant can become a human being, one would also have to accept as truth that the nymph Daphne was transformed into a laurel tree. ${ }^{95}$ We have already encountered a similar argument in Maximus.

91 This feature has no bearing on the polemic against the Armenians. Therefore we can be certain that it reflects Photius' personal opinion.

92 Arethas, Opusculum 56; ed. L.G. Westerink, Arethae archiepiscopi Caesariensis scripta minora, 1. Leipzig 1968, 340-362.

93 Arethas, Opusculum 56.3-4; ed. WESTERINK, 346.6-14. Nicetas was deeply involved in church politics. His Life of Patriarch Ignatius is an anti-Photian pamphlet. For a comprehensive

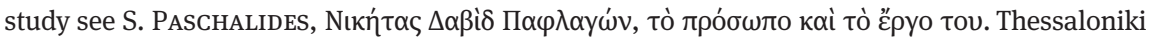
1999.

94 Arethas, Opusculum 56, pinax; ed. WESTERINK, 342.13-14.

95 Arethas, Opusculum 56.5; ed. WESTERINK, 346.15-19. 
That Arethas should dismiss Aristotelian teaching in such an off-hand way is surprising since he composed scholia on the Categories and in general showed great interest in ancient philosophy. ${ }^{96}$ Yet it is not difficult to see why he took this stance. He was concerned that the soul might lose its status as a self-sufficient being. He complains that it would die with the body like the souls of animals if it could only function when the organs are fully formed. ${ }^{97}$ This was, of course, a view that nobody held at the time. Yet it is worth noting that Babai believed the soul was dependent on the body and would become unconscious after death. ${ }^{98}$

It is not always easy to get a sense of the arguments since the text is not a technical treatise like the Liber de anima but a rhetorical tour de force. Yet some observations can be made. In one case Arethas responds to the objection that the soul does not remember its stay in the womb by stating that it was overwhelmed by the matter that surrounded it. ${ }^{99}$ In another case we encounter a string of arguments and counterarguments. The champions of methyparxis declared that the nutritive soul was responsible for the formation of the body. When their opponents told them that the human being would then be controlled by an 'irrational nature' ( $\alpha$ '

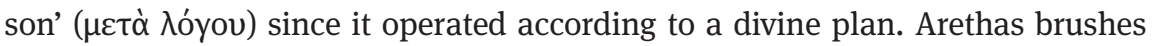
off this reasoning and asserts that the natural processes are controlled by the rational soul. ${ }^{100}$

Twice he mentions arguments that were already found in earlier texts, that synhyparxis was an Origenist teaching, and that the punishment for those who cause a miscarriage proves methyparxis. In the first case he has this to say.

'Елàv yó

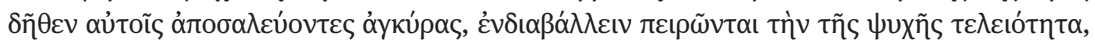

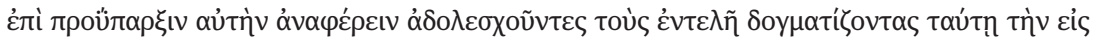

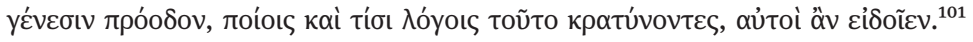

96 See P. Kotzia-Panteli, On Arethas of Caesarea's scholia on Porphyry's Isagoge and Aristotle's Categories. Hellenika 46 (1996), 396-410; and J. WhitTAKER, Arethas and the "Collection philosophique”, in D. Harlfinger / G. Prato (eds.), Paleografia e codicologia greca. Atti del II Colloquio internazionale Berlino-Wolfenbüttel, 17 - 21 ottobre 1983. Alessandria 1991, 513-521. 97 Arethas, Opusculum 56.13; ed. WESTERINK, 349.18-350.7.

98 See e.g. F. Gavin, The sleep of the soul in the early Syriac church. Journal of the American Oriental Society 40 (1920), $103-120$, esp. 107.

99 Arethas, Opusculum 56.8; ed. WESTERINK, 348.13-25.

100 Arethas, Opusculum 56.7; ed. WeSterink, 347.20-348.12.

101 Arethas, Opusculum 56.15; ed. Westerink, 351.8-14. 
For when some people are thunderstruck by the truth of such arguments, they ride at a single anchor that is supposedly sacred to them, and attempt to slander the completeness of the soul, prating that those who in their doctrines accord to it a progression to coming-tobe that is complete, they themselves will know, with which and what kind of arguments they support this view.

According to Arethas such an opinion gives the impression as if God was constrained in his actions by fear of being misunderstood by human beings, which would be ridiculous. In the second case the reasoning goes as follows.

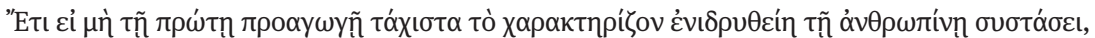

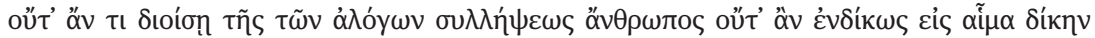

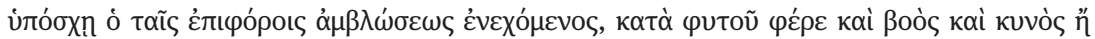

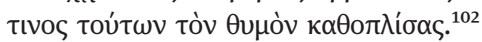

Furthermore, if that which imprints were not established in the human constitution right at the first production, the human being would not differ in anything from the conception of beasts, nor would the one who is liable for the miscarriage of pregnant women justly incur the penalty of losing his life, since he would have armed his anger against a plant, perhaps, and a cow and a dog or any one of these.

At first one might think that this refers to Exodus 21:22 since Arethas speaks of anger. Yet it would be very odd if this were the case because the statement flatly contradicts the Biblical verse. Thus it seems more likely that Arethas appealed to contemporary law. ${ }^{103}$ This was a clever move, because previous attempts by Maximus and Moses Bar Kepha to reinterpret Exodus 21:22 had been quite unsatisfactory.

In the second part of his treatise Arethas discusses the implications of methyparxis for the union of the Word with the flesh.

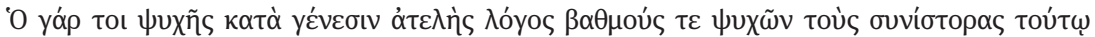

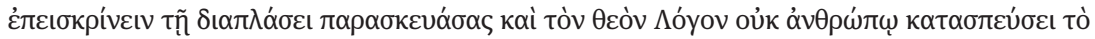

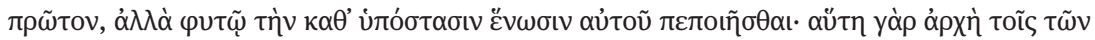

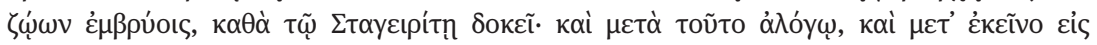

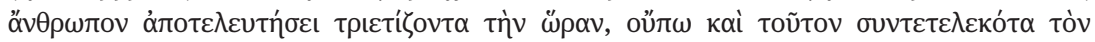

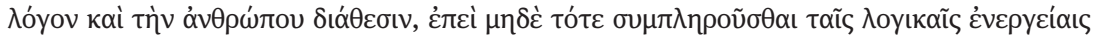

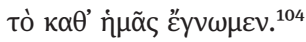

102 Arethas, Opusculum 56.12; ed. WeSterink, 349.11-16.

103 See C. Cupane / E. Kislinger, Bemerkungen zur Abtreibung in Byzanz. JÖB 35 (1985), 21 49, esp. $25-27$.

104 Arethas, Opusculum 56.16; ed. Westerink, 352.21-353.1. 
For the incomplete account of the soul as regards its coming-to-be causes the experts to insert stages of souls into the formation and leads to the rash conclusion that the divine Word effects his hypostatic union at first not with a human being, but with a plant, for this is the beginning for the embryos of living beings, according to the opinion of the Stagirite, and afterwards with a beast, and after that it will end up being a human being, who is three years old, since we have learnt that even then our existence is not completed as regards the rational operations.

Here we get another summary of Aristotelian embryology, which is then summarily dismissed with the quotation from Gregory of Nazianzus that had already been produced by the anonymous Nestorian and by Maximus. ${ }^{105}$ Unlike earlier authors, Arethas claims that if one accepted methyparxis the rational soul would only appear when a child is three years old, or even later. This is a rather extreme interpretation of Aristotle's teachings. The subsequent paragraph shows why it appears in the text. There Arethas refers to the Biblical story of the twelveyear-old Jesus who confounded those present in the temple with his wisdom. ${ }^{106}$ This story becomes the starting point for a complex argument.

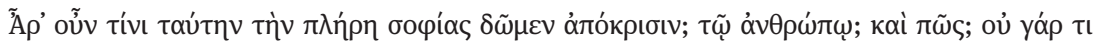

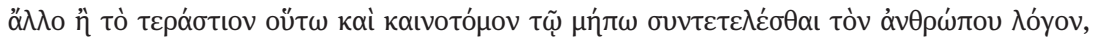

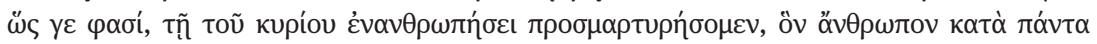

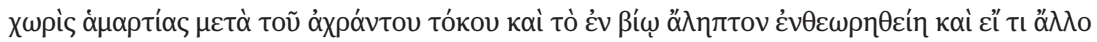

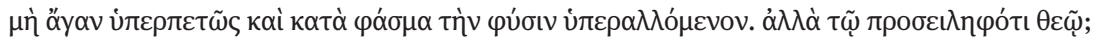

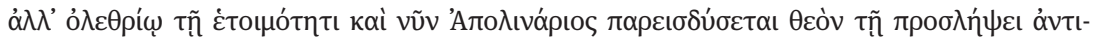

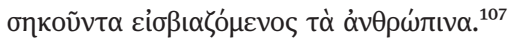

To whom then shall we attribute this answer, which is full of wisdom? (1) To the human being? But how? For if the reason of the human being is not yet accomplished, as they say, we will ascribe to the inhumanation of the Lord nothing else but monstrosity and innovation. One can see that this one is in all respects a human being, together with the undefiled birth and the irreproachable conduct, and whatever else there is that does not transcend the nature in an extremely lofty way, which would turn it into a phantom. (2) Or to the god who assumed it? But then Apollinaris will now, too, slip in with destructive readiness, forcing God to counterbalance through assumption that which is human.

The purpose of this argument is to show that the soul must be complete from the moment of conception. It is claimed that what Jesus did was potentially possible for ordinary human beings as well. Arethas states that otherwise Jesus' preco-

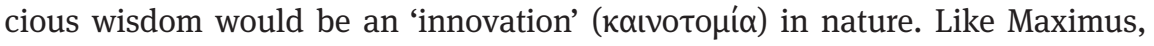

105 Ibid., 353.10-13.

106 Luke 2:41-52.

107 Arethas, Opusculum 56.18; ed. WeSTERINK, 355.8-18. 
Arethas appeals to Hebrews 4:7 in order to emphasise that Christ's humanity cannot be categorically different from ours. Yet he also has to contend with the troubling notion that Christ's birth was without corruption. Maximus had explained this feature away by claiming that corruption was a consequence of the fall. Arethas does not avail himself of this argument, instead adding the rather lame comment that features of this kind are not 'very supernatural'. In a second step he then plays the heresiological card. He claims that those who accept that ordinary human beings receive their rational soul only later are necessarily followers of Apollinaris of Laodicea who taught that in Christ the place of the human rational soul was taken up by the divinity. ${ }^{108}$ This is clearly a specious argument. It does not consider the possibility that Christ's soul could have been strengthened by the Holy Spirit so as to be able to do things that are beyond the reach of ordinary human beings.

At this point we need to ask: was there a debate about embryology in Constantinople at the beginning of the tenth century? As I have already mentioned Arethas wrote his treatise after a conversation with Nicetas the Paphlagonian who appears to have defended the notion of methyparxis. Unfortunately, the account of this conversation is no longer extant as the folio is missing in the manuscript. We only find the brief comment that the tone had been irenic. ${ }^{109}$ Moreover, we do not know whether Nicetas had produced all the arguments that are refuted in Arethas' treatise. In the end, we cannot entirely rule out the possibility that the discussion was merely an intellectual game. ${ }^{110}$ Even if this is the case, however, we can see very clearly that Byzantine intellectuals of the time had a very good knowledge of the debate and its terms. It may well be that they had access to further texts, which are now lost.

To conclude: The notion that the soul comes into existence simultaneously with the body at the moment of conception was originally introduced into the Patristic discourse as an alternative to the Origenist notion of a pre-existing soul. Yet in the course of the sixth century, when anti-Origenist sentiment intensified, many people came to the conclusion that synhyparxis was simply a front behind which the Origenists hid, probably not without justification, as some authors indeed tried to smuggle in the concept. Instead, they promoted methyparxis as a

108 On Apollinaris see T.J. CARTER, The Apollinarian Christologies: a study of the writings of Apollinarius of Laodicea. PhD thesis, Heythrop College University of London 2007, 148-155. 109 Arethas, Opusculum 56.22; ed. WeStERINK, 362.8-14.

110 Indeed, in other sources Nicetas is accused of Origenist leanings. See D. KRAUSMÜLLER, What is paradise and who is in it? The discussion about the abode of the souls of the righteous in sixth- to eleventh-century Byzantium. Byzantinoslavica 76 (2018), 45-57, esp. 54-55. 
safe option, although the sources show that even it could be subverted. The Christological controversies also had an impact on the debate. The Chalcedonians and Monophysites had to subscribe to synhyparxis in the case of Christ because otherwise they could not show that the union resulted in one hypostasis or nature. By contrast, the Nestorians who posited a much looser relationship between humanity and divinity opted for methyparxis. The Nestorians and some Chalcedonians insisted that there was no categorical difference between the coming-to-be of Christ's humanity and ordinary human beings, since according to Scripture Christ was in all respects like us apart from sin. Other Chalcedonians, for fear of being tarred with the Origenist brush, claimed that in ordinary human beings the soul appeared after the body whereas Christ was a special case and synhyparxis was a supernatural feature, along with conception without semen and birth without corruption. They could come to this conclusion because they put less emphasis on the full humanity of Christ. 
